\title{
THE COMPETENCIES OF NEWLY QUALIFIED PSYCHIATRIC NURSES
}

\section{Lunice B Khoza}

D Litt. et Phil.

Senior Lecturer, Department of Nursing,

University of the North.

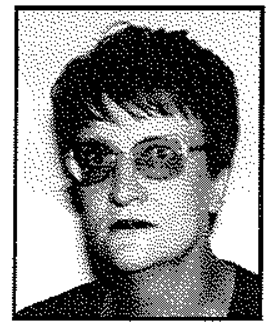

Valerie J Ehlers

$D$ Litt. et Phil.

Senior Lecturer, Department of Advanced Nursing Sciences, University of South Africa (UNISA)

\section{ABSTRACT}

This research report comprises part of a larger study, which endeavoured to identify the competencies of newly qualified nurses (NQNS) as viewed by senior professional nurses (SPNS) in the clinical units. This report concentrates only on the competencies of the NQNS working in the psychiatric nursing units. SPNS $(N=29)$ from certain health services in the Northern Province (NP) of the RSA, constituted the population for this research. A descriptive survey was used as a research approach to conduct this research. The fieldwork, entailing the distribution and collection of the questionnaires by a researcher, was done during a period of political and labour unrest in this area. Consequently, only certain health services granted permission for this research to be conducted; others refused permission fearing escalations in the unrest which prevailed at the time.

The findings revealed that specific cognitive, affective and psychomotor competencies were expected from the NQNS upon entering the psychiatric work setting, as perceived by SPNS. NQNS in the psychiatric clinical units were perceived to be competent in performing numerous, but not all, clinical competencies contained in the questionnaire.

\section{OPSOMMING}

Hierdie verslag handel net oor 'n deel van ' $n$ groter studie wat gepoog het om die bedrewenhede van pas gekwalifiseerde verpleegkundiges ("newly qualified nurses - NQNS") te identifiseer soos waargeneem deur senior professionele verpleegkundiges ("senior professional nurses - SPNs"). Die verslag fokus net op die bedrewenhede van NQNs in die psigiatriese eenhede. Die navorsingpopulasie het bestaan uit SPNs $(n=29)$ van sekere gesondheidsdienste in die Noordelike Provinsie (NP) van die RSA. ' $n$ Beskrywende opname is benut as navorsingsbenadering ten einde die navorsing te doen. Die veldwerk, wat die uitdeel en insameling van vraelyste deur ' $n$ navorser behels het, is gedoen tydens 'n periode van politieke en arbeidsonrus in die gebied. Gevolglik het net sekere gesondheidsdienste toestemming verleen vir die navorsing; ander het toestemming geweier omdat hulle verhoogde onrus gevrees het.

Die navorsingsbevindinge het aangedui dat spesifieke kognitiewe, affektiewe en psigomotoriese bedrewenhede van NQNS verwag is wanneer hulle die arbeidsveld betree, soos waargeneem deur die SPNs. NQNS in die psigiatriese kliniese eenhede was beskou as synde bedrewe in die vervulling van baie, maar nie in alle bedrewenhede wat in die vraelys vervat is nie.

\section{INTRODUCTION}

The definitions of competency as depicted in the literature, share common concepts such as ability, quality, performance, efficiency and capability. In this report “competency" refers to NQNs' cognitive, affective, and psychomotor abilities to perform specific tasks satisfactorily as reported by SPNs working in psychiatric units in the NP. This definition of competency concurs with that of Searle \& Pera (1992:92) defining competency as 
"a demonstrated cognitive, affective and/or psychomotor ability required for the performance of specific activities".

For the purposes of this report, a NQN is a professional nurse who has fulfilled the requirements of the South African Nursing Council's (SANC's) Regulation no. 425 (R425) of 22 February 1985, as amended, and who qualified as a nurse (general, psychiatric and community) and a midwife, with less than one year's clinical experience. NQNs' acts and procedures are determined by the scope of practice of registered nurses as legislated and circumscribed by the SANC's Regulation 2598 (R2598) of November 1984, as amended.

Since 1983, concerns have been experienced by health professionals that NQNs who completed the comprehensive course (R425) leading to registration as a nurse (general, community and psychiatric) and midwife, were perceived to have inadequate knowledge for rendering psychiatric, midwifery and community health services. Concerned health care professionals, including nurses, doubted whether these comprehensively trained diplomats could handle practical procedures adequately in the clinical nursing units (RHOSA memorandum $4 \mathrm{Au}-$ gust 1992). These concerns were often related to the duration of training. The comprehensive (R425) course enabled students to become registered general-, psychiatric-, community health nurses as well as midwives upon successfully completing the four-year course. Prior to the implementation of the R425 course (during 1983), students required three years to become registered general nurses and one year for each of the other three qualifications; thus six-year programmes were condensed to four-year programmes.

Upon completion of their training, NQNs are expected to have developed analytic styles, critical, evaluative and creative thinking, and the continuing stimulation of the capacity to interpret scientific data for nursing actions, to draw conclusions and to exercise independent judgement (SANC, 1992:3). This research endeavoured to identify specific cognitive, psychomotor and affective psychiatric nursing skills which Senior Professional
Nurses (SPNs) expected NQNs to possess, and to establish whether or not the SPNs regarded the NQNs as meeting these expectations. (SPNs in this study refer to professional nurses who have been promoted to this rank, usually after a minimum of three years' clinical experience, and who are directly involved in the psychiatric clinical settings in which the NQNs were working at the time of collecting the data).

Clinical competency demands the acquisition of higher level behaviours in the cognitive, affective and psychomotor domains of learning. Fitzpatrick, White \& Roberts (1992) reviewed literature which revealed a range of the nurse's subrules within the service of nursing. They support the view that competency in psychomotor, cognitive and affective competencies is required for performance within each of these subrules to achieve the delivery of high quality nursing. That is, use of the nursing process, use of research in practice, communication competencies, care management and organisation of workload, and the role of the nurse in health education.

Information regarding the competencies of NQNs, as perceived by SPNs, might render valuable contributions towards improving nursing education programmes in the RSA. Such information could provide curriculum developers with realistic input regarding competencies acquired and competencies showing a deficiency. This should assist in the delineation and refinement of the professional competencies expected for nurses trained in the comprehensive course leading to registration as a nurse (general, psychiatric and community) and midwife. Nurse educators need to investigate the performance of NQNs in order to evaluate whether or not they are preparing nurses who are able to use their education in carrying out their responsibility for providing high quality care. This survey could serve as a platform for future studies with competency-based orientations.

The research findings, obtained from the questionnaires completed by the SPNs, are displayed in Tables 1 and 2 . These findings revealed that NQNs in the psychiatric units were viewed by their SPNs to lack competency in 
performing psychomotor and cognitive activities, but to be competent in performing nursing functions falling within the affective domain.

\section{OVERVIEW OF THE LITERATURE}

A review of the literature confirms that psychiatric nurses are expected to be competent in performing the caring and interpersonal relationship nursing activities. In a study done by Edwards (1995) in England, the users of psychiatric services commented on the competencies and qualities required of mental health nurses. These included showing respect and being reassuring, listening skills, explaining and giving information, counselling skills, being able relate to one as an individual, and to provide touch and comfort. These findings concurred with nursing students' views, who participated in this study. Furthermore these students, inter alia, regarded the following to be important in their learning: teaching skills, management, observing and monitoring, counselling, research skills, theory-based practice, and the prescribing of medicines.

A study done by Doorbos (1997) augmented these psychiatric nurses' expectations by suggesting other competencies such as improving spiritual dimensions, that is showing love, forgiveness and hopefulness. Furthermore the nurse as teacher was also highlighted in order to present information about mental illness and the nurse as referral agent was also regarded as being important so that the nurse will be able to identify the usefulness of support groups and various community resources.

A study done by Monkey-Poole (1995) identified the most common skills practised by English psychiatric nurses to include bereavement counselling and general counselling. Gujbels (1995) revealed that psychiatric nurses needed to have a wide range of skills involving problem-solving. This was important for effective referrals to other disciplines. Furthermore, nurses valued interpersonal relationships with patients, but the research findings revealed that this was difficult to achieve adequately due to a lack of continuity of care. Troskie (1993) in the RSA, compared NQNs' problem- solving abilities in the psychiatric, community and midwifery areas. Results indicated that NQNs in the psychiatric hospital were better problem-solvers than the community health nurses and midwives.

Landeen, Byme \& Brown (1995) revealed that many psychiatric nursing students indicated that they felt inadequately prepared to function in given situations. All psychiatric senior nursing students $(n=18)$ identified communication skills and the maintenance of therapeutic relationships as being critical to working with psychiatric clients. However, they also disclosed feeling very inexperienced in these respects (Landeen et al. 1995).

Feely (1997:115-116) indicates that effective interpersonal relations do help nurses to identify the appropriate nursing care strategies for specific patients/clients. She describes the psychiatric nurse's roles as comprising those of teacher, leader, counsellor, resource person and surrogate. These roles require the mastery of specific competencies.

\section{RESEARCH PURPOSE AND RESEARCH QUESTIONS}

This reported research endeavoured to determine the competencies of NQNs appointed in the psychiatric clinical units in the NP of the RSA. The purpose of this study was to identify the competencies which SPNs expect of NQNs, and to identify the psychomotor, affective and cognitive competencies displayed by NQNs, as perceived by SPNs. To achieve this, specific questions were formulated:

- What competencies do SPNs expect NQNs to have upon entering the psychiatric nursing work setting? Which cognitive, psychomotor and affective competencies do NQNs have upon entering the psychiatric work setting, as perceived by SPNs?

Which factors, according to the SPNs' perceptions, could contribute towards NQNs' perceived incompetence? 


\section{Research Design}

An exploratory descriptive survey was employed to investigate the competencies of NQNs in the psychiatric units in the Northern Province, as viewed by the SPNs . The study used questionnaires for collecting data. After an extensive literature review about nurses' expected competencies, the items for the questionnaire were selected based on $\mathrm{R} 2598$ (the regulation defining the scope of practice of the registered nurse in the RSA).

\section{The Construction of the Questionnaire}

Section one of the questionnaires requested SPNs to supply general information portraying their profiles in their working situations.

Section two comprised of Part A, attempting to identify which competencies SPNs expected NQNs to have upon entering the work setting and Part B requesting the SPNs to indicate whether or not the NQNs possessed the relevant competencies. Part A used four-point scale requiring SPNs to respond according to the following key, indicating which competencies they expected NQNs to have upon entering the work setting:

. 1 essential competency upon entering the work setting

- 2 desirable but not essential

- 3 useful but not essential and not expected from NQNs

- 4 non-nursing, not considered part of the nurses' competencies.

In analysing the completed questionnaires' data, maintaining four categories proved to provide limited information due to the small number of respondents. At the advice of a statistician from the University of South Africa, responses falling within Categories 1 and 2 in Section $\mathrm{A}$ of the questionnaire were grouped together to indicate essential competencies, whilst those falling within categories 3 and 4 were accepted to indicate nonessential competencies. In cases where 50 per cent or more of the respondents indicated that a competency was not essential for NQNs by ticking categories 3 or 4 this competency was then accepted to be non-essential, as perceived by the SPNs participating in this survey.
Part B attempted to establish whether or not the SPNs perceived the NQNs as having mastered each competency, according to the following four-point scale based on the work of Benner (1984):

1 mastery: able to perform competently and efficiently without supervision

2 competent: able to perform without supervi sion and with reasonable efficiency

3 performance is unsafe, incompetent, and re quires further practice and supervision

4 non-nursing competency: SPN considered this competency as not forming part of the nurse's role.

Responses falling within Categories 1 and 2 were grouped together as indicating NQNs' competence in performing these aspects, whilst those falling within Categories 3 and 4 were grouped together as indicating NQNs' incompetence. In cases where 50 per cent or more of the SPNs' responses fell within Categories 1 and 2, NQNs were perceived to be competent, whilst NQNs were perceived to be incompetent in those aspects where 50 per cent or more of the SPNs' responses fell within Categories 3 and 4.

Section three of the questionnaire consisted of both open and closed-ended questions attempting to identify SPNs' perceptions about NQNs' competency deficiencies, and suggestions for enhancing NQNs' competencies.

\section{The Validity and Reliability of the Research In- strument}

"The validity of an instrument is a determination of the extent to which the instrument actually reflects the abstract concept being examined" (Burns \& Grove, 1987:294). The reliability of a research instrument is "... the degree of consistency with which it measures the attribute it is supposed to be measuring... reliability can be equated with the stability, consistency, or dependability of a measuring tool" (Polit \& Hungler, 1989:242). In preparing the questionnaire for conducting this exploratory survey, it was not possible to test the instru- 
ment repeatedly because a limited number of SPNs could participate in this study which pre-tests would have reduced even further. Access to health care services was problematic due to labour unrest, and the researcher was granted permission to visit each institution once only. In order to obtain content validity the questionnaires were completed by clinical psychiatric nurse tutors, not forming part of the survey's population of SPNs in the NP. The clinical psychiatric nurse tutors recommended a few minor changes. These completed questionnaires were analysed by computer, using the SAS programme, in order to establish the feasibility of subjecting the completed questionnaires to computerised statistical analyses.

The participating SPNs were guided about the completion of the questionnaires, reducing the chances of ambiguity or misinterpretations. A researcher delivered the questionnaires at a specific institution and remained there until the completed questionnaires had been returned, being available for any clarifications.

(An example of a questionnaire is not included due to the length of this report and because Tables 1 and 2 reflect the items contained in the questionnaire).

\section{The Distribution of the Questionnaires}

Questionnaires were delivered and collected by the researcher. SPNs $(n=29)$ working at thirteen hospitals in the Northern Province constituted the population of this study. Scientific sampling techniques were not employed as all subjects participated in the study.

\section{Permission to conduct the research}

This permission was granted by the health authorities of the Northern Province and by the nursing service administrators as well as medical superintendents of the health care institutions participating in this research project. The SPNs who completed the questionnaires did so freely, anonymously and during their own time.

\section{Research Results}

Frequencies were computed to determine the percentages attributed to each individual item in the questionnaire. The findings revealed that the majority of the respondents, SPNs $(n=29)$ fell within the ages $31-40$ years (59\%). Only one SPN was older than 50 years of age. The largest number (23) of SPNs had 1-10 years of experience as SPNs working in the psychiatric clinical units. All SPNs $(n=29)$ were qualified psychiatric nurses. No respondent (SPN) completed a course in advanced psychiatric nursing.

SPNs were required to evaluate NQNs' performances in the psychiatric nursing units. A number of SPNs $(n=29)$ responded positively. The following statements were regarded as implying positive opinions concerning the NQNs' performances:

NQNs were not perfect, they needed supervision and guidance in the wards $(75 \%)$.

It might be difficult to adjust to psychiatric clinical units, NQNs would cope in due course $(50 \%)$.

- NQNs tried their best to improve their practice by asking many questions (63\%).

- NQNs were reliable $(63 \%)$.

- NQNs needed to be given a chance, they would grow $(88 \%)$.

- NQNs realised that they should assume responsibility, and SPNs supported the NQNs (100\%).

These findings seem to concur with the findings reported by Landeen et al. (1995:882) who found that student nurses, felt that the staff, implying the senior nurses, really cared about the students' education and wanted to facilitate their learning.

However, a number of SPNs ( $\mathrm{n}=29$ ) also revealed negative perceptions concerning the NQNs' perceived capabilities in the psychiatric units in their responses on the questionnaires, such as:

NQNs made blunders everyday (86\%).

They are always under the umbrella of their seniors, they would not grow $(71 \%)$.

Patients were not safe $(86 \%)$.

NQNs should be careful or they would receive hidings from patients, they did not display sufficient tact towards their patients/clients (54\%). 


\section{TABLE 1: NQNs' COMPETENCIES PERVEIVED TO BE ESSENTIAL BY SPN'S IN THE PSYCHIATRIC NURSING UNITS (PART A): AND NQN'S ACTUAL COMPETENCIES AS VIEWED BY THE SPN'S (PART B).}

\begin{tabular}{|c|c|c|c|}
\hline \multirow[t]{2}{*}{ COMPETENCIES } & \multirow[b]{2}{*}{$F$} & \multicolumn{2}{|l|}{$\% n=29$} \\
\hline & & PART A & PART B \\
\hline Cognitive skills: & & & \\
\hline $\begin{array}{l}1 \text { Obtain adequate information from a psychiatric patient and } \\
\text { the family. }\end{array}$ & 29 & 100 & 62 \\
\hline 2 Assess patient's physical and psychosocial needs. & 29 & 93 & 5 \\
\hline 3 Define a patient's problem. & 29 & 89 & 41 \\
\hline 4 Formulate a nursing care plan. & 29 & 96 & 96 \\
\hline $\begin{array}{l}5 \text { Discriminate and synthesise information obtained from } \\
\text { assessment. }\end{array}$ & 29 & 93 & 45 \\
\hline $\begin{array}{l}6 \text { Interpret verbal and non-verbal cues from mentally ill patient. } \\
7 \text { Prioritise patients' problems. }\end{array}$ & 29 & 86 & 73 \\
\hline 8 Record accurately nursing diagnosis. & 29 & 97 & 72 \\
\hline 9 Clearly state one's assessment of a mentally ill patient. & 29 & 100 & 72 \\
\hline $\begin{array}{l}10 \text { Specify nursing intervention in order to priority. } \\
11 \text { Identify preventive actions to minimise patient risk. }\end{array}$ & 29 & 100 & 40 \\
\hline 12 Plan and organise one's working day teaching. & 29 & 100 & 31 \\
\hline 13 Identify learning needs of the mentally ill patient, the family & 29 & 100 & 45 \\
\hline $\begin{array}{l}\text { and nursing students. } \\
14 \text { Set objectives for teaching. }\end{array}$ & 29 & 97 & 57 \\
\hline 15 Use teaching strategies effectively. & 29 & 93 & 66 \\
\hline $\begin{array}{l}\text { is Select teaching aids suitable for teaching a mentally ill } \\
\text { patient. }\end{array}$ & 29 & 83 & 52 \\
\hline 17 Teach patient's family about patient's needs. & 29 & 89 & 64 \\
\hline 18 Demonstrate effective communication skills. & 29 & 89 & 82 \\
\hline 19 Evaluate learning. & 28 & 93 & 79 \\
\hline $\begin{array}{l}20 \text { Design educational programmes for clients and nursing } \\
\text { students. }\end{array}$ & 29 & 73 & 38 \\
\hline & 29 & 90 & 40 \\
\hline Management: & & & \\
\hline 21 Produce clear and accurate report. & 28 & 89 & 59 \\
\hline 22 Delegate aspects of care to peers. & 29 & 82 & 72 \\
\hline 23 Implement policies and procedures as needed. & 29 & 89 & 54 \\
\hline 24 Manage crisis intervention. & 29 & 68 & 10 \\
\hline 25 Manage stress. & 29 & 70 & 11 \\
\hline 26 Carry out admission and discharge of patients according to & & & \\
\hline Mental Health Act, no 18 of 1973. & 29 & 66 & 44 \\
\hline 27 Evaluate own practice. & 29 & 79 & 62 \\
\hline 28 Commit oneself to unit objectives. & 29 & 90 & 62 \\
\hline $\begin{array}{l}\text { Affective skills: } \\
\text { Adaptiveladjustive }\end{array}$ & & & \\
\hline 29 Be sensitive to people's feelings. & 29 & 69 & 72 \\
\hline 30 Accept criticism from staff. & 29 & 72 & 72 \\
\hline 31 Be confident in oneself nursing ability (practices) & 29 & 55 & 41 \\
\hline 32 Adjust to work environment. & 29 & 50 & 66 \\
\hline
\end{tabular}

\begin{tabular}{|c|c|c|c|}
\hline \multirow[t]{2}{*}{ COMPETENCIES } & & \multicolumn{2}{|l|}{$\% n=29$} \\
\hline & $F$ & PART A & PART B \\
\hline \multicolumn{4}{|l|}{ Interpersonal/Communication: } \\
\hline 33 Communicate a feeling of accepiance of each patient. & 29 & 93 & 79 \\
\hline 34 Promote the patient's right to privacy. & 29 & 86 & 83 \\
\hline 35 Explain nursing procedures to patients prior performing & 29 & 90 & 80 \\
\hline them. & 28 & 90 & 72 \\
\hline 36 Communicate information to other health team members. & 29 & 90 & 59 \\
\hline 37 Apply the therapeutic touch. & 29 & 90 & 79 \\
\hline 38 Caring for a patient who is displaying anxiousness. & 29 & 90 & 79 \\
\hline 39 Seek assistance when necessary. & & & \\
\hline \multicolumn{4}{|l|}{ Caring and Ethics: } \\
\hline 40 Create safe environment for patients. & 29 & 97 & $7 \hat{9}$ \\
\hline 41 Listen to patients. & 29 & 97 & 82 \\
\hline \multicolumn{4}{|l|}{42 Support human dignity while engaging to professional } \\
\hline practice. & 29 & 90 & 72 \\
\hline 43 Respect patient's freedom of thoice. & 29 & 90 & 72 \\
\hline 44 Inform a patient about his progress. & 29 & 90 & 45 \\
\hline 45 Alleviate a patient's stress and anxiety. & 29 & 90 & 41 \\
\hline 46 Exercise patience with demanding patients. & 29 & 86 & 62 \\
\hline 47 Practise within the scope of practice of a professional nurse. & 29 & 82 & 79 \\
\hline 48 Demonstrate knowledge of the ethics of nursing. & 29 & 83 & 76 \\
\hline \multicolumn{4}{|l|}{$\begin{array}{l}49 \text { Contribute to the growth of olhers by sharing knowledge and } \\
\text { expertise. }\end{array}$} \\
\hline expertise. & 29 & 76 & 69 \\
\hline \multicolumn{4}{|l|}{ Psychomotor skills: } \\
\hline \multirow{2}{*}{\multicolumn{4}{|c|}{$\begin{array}{l}50 \text { Measure, monitor accurately pulse, temperature, respiration } \\
\text { and blood pressure. }\end{array}$}} \\
\hline & & 90 & 90 \\
\hline 51 Interpret vital data. & 29 & 97 & 97 \\
\hline 52 Recognise and intervene in the threatening situations. & 29 & 93 & 90 \\
\hline 53 Observe, monitor and record intake and output. & 29 & 70 & 31 \\
\hline 54 Identify and intervene in deviations from normal behaviour. & 29 & 90 & 79 \\
\hline 55 Function in appropriate role in fre/disaster procedure. & 29 & 79 & 48 \\
\hline 56 Check blood products for proper identification. & 29 & 52 & 25 \\
\hline 57 Employ suicide precautions. & 29 & 90 & 66 \\
\hline 58 Employ medico-legal risk precautions. & 29 & 97 & 69 \\
\hline 59 Apply physical restrains to violent patients. & 29 & 97 & 41 \\
\hline 60 Administer and supervise oral care. & 29 & 64 & 52 \\
\hline 61 Administer and supervise skin care. & 29 & 68 & 46 \\
\hline 62 Assess nutritional status of a patient. & 26 & 97 & 97 \\
\hline 63 Feed a helpless patient. & 27 & 88 & 66 \\
\hline 64 Prepare and administer medication safely & 27 & 97 & 72 \\
\hline 65 Dilute intravenous medication aseptically. & 29 & 90 & 62 \\
\hline 66 Add medication into IV therapy without contamination. & 26 & 86 & 64 \\
\hline 67 Give IV medication through a drip chamber. & 26 & 97 & 69 \\
\hline \multicolumn{4}{|l|}{68 Demonstrate knowledge on the use of psychiatric } \\
\hline medication. & 29 & 79 & 72 \\
\hline 69 Prescribe medication for mentally il patient. & 29 & 90 & 61 \\
\hline 70 Detect untoward symptoms from medication. & 29 & 86 & 48 \\
\hline 71 Control schedule 5,6 and 7 medication. & 29 & 90 & 74 \\
\hline 72 Position patient for optimum ventilation. & 26 & 52 & 51 \\
\hline 73 Perform urine testing. & 25 & 55 & 62 \\
\hline
\end{tabular}

Landeen et al. (1995:882) obtained similar negative experiences expressed by psychiatric senior nursing students such as "A few of the staff referred to me as just the student. It could be my knowledge or my innocence that they envy".

Table 1 represents the competencies perceived to be essential by SPNs in the psychiatric nursing units (Part A), and the actual competencies of NQNs (Part B), as perceived by the SPNs. All competencies perceived to be essential by at least $50 \%$ of the SPNs in part A were accepted as being essential (expected competencies of
NQNs upon entering the psychiatric nursing work setting) in this study.

Table 1 reveals that specific cognitive, affective and psychomotor competencies were expected of NQNs upon entering the work setting, as perceived by SPNs. NQNs were perceived to be competent in performing numerous, but not all, clinical competencies which were outlined in the questionnaire. Application of stages of the nursing process, clinical judgement, research and critical care were perceived by the SPNs to be the central focus of NQNs' incompetence in the psychiatric 
units.

The findings revealed that NQNs were perceived by SPNs to be competent in performing affective competencies related to caring and interpersonal relationships and administration and management. These competencies have also been identified as essential in psychiatric units by various other authors (such as Doornbos 1997; Edwards 1995; Feely 1997; Monkley-Poole 1995). Landeen et al. (1995) found that psychiatric senior nursing students felt inadequate in performing communication skills and in maintaining therapeutic relationships.

NQNs in this study were perceived by the SPNs to be competent in performing administration and management skills. However, admission and discharge policies and practices were areas identified as major constraints requiring improved performance by the NQNs, according to the SPNs' perceptions. NQNs in this study were perceived by SPNs to be incompetent in carrying out admissions and discharges according to the stipulations of the RSA's Mental Health Act, (No 18 of 1973, as amended). Gujbels (1995) also found that psychiatric nurses indicated that administration duties took a priority over therapeutic activities, spending up to $90 \%$ of their time in the office.

Table 2 reveals competencies which were perceived by SPNs to be non-essential in the psychiatric unit. Research appears to be commonly understood as being a non-essential nursing competency as revealed in studies done by Troskie (1993), Ehrenfeld \& Eckerling (1991), and Joyce-Nagata, Reebs \& Burch (1989). Research could be of importance in the improvement of psychiatric nursing practice and the growth of scientific psychiatric nursing knowledge.

SPNs regarded most psychomotor competencies to also be non-essential in the psychiatric units. This could imply that the clinical experiences of psychiatric nurses focus on the psycho-social components with relatively little attention given to the physical and physiological imbalances of a patient. Gujbels (1995) indicated that psychiatric nurses needed to have a wide range of skills, not only expertise in psychological interventions. Edwards (1995) reported that psychiatric student nurses needed to be skilled in a variety of cognitive and psychomotor nursing functions.

Patients in the psychiatric clinical units might have cardiac arrests due to adverse reactions to medications, requiring urgent cardio-pulmonary resuscitation; patients might become psychotic due to electrolyte imbalances and might require collection of urine and blood specimens for investigation; patients might need nutritional supplements through naso-gastric tube feeds. SPNs in the psychiatric nursing units could facilitate development of competency by NQNs by influencing NQNs to care for physical illnesses of psychiatric patients in the

TABLE 2: THE COMPETENCIES PERCEIVED TO BE NON-ESSENTIAL BY SPN'S IN THE PSYCHIATRIC UNITS (PART A) AND THE COMPETENCIES OF NQN'S AS PERCEIVED BY SPN'S (PART B).

\begin{tabular}{|c|c|c|c|}
\hline COMPETENCIES & & $\% n=29$ & \\
\hline & $\mathbf{F}$ & PART A & PART B \\
\hline $\begin{array}{l}1 \text { Identify researchable psychiatric problems. } \\
2 \text { Initiate research. } \\
3 \text { Read and critically analyse research. } \\
4 \text { Use research data. } \\
5 \text { Determine the applicability of the results in the clinical } \\
\text { setting. } \\
6 \text { Work under pressure. } \\
\text { Psychomotor skills: } \\
1 \text { Feed patient per nasogastric tube. } \\
2 \text { Perform a venepuncture for IV infusion. } \\
3 \text { Set sterile trolley for special procedures. } \\
4 \text { Prepare a patient for operation. } \\
5 \text { Use instruments in a sterile field. } \\
6 \text { Suture wounds. } \\
7 \text { Dress wounds. } \\
8 \text { Apply local anaesthetic. } \\
9 \text { Collect specimens for investigations (urine; blood). } \\
10 \text { Insert an indwelling urinary catheter. } \\
11 \text { Introduce an oropharyngeal airway. } \\
12 \text { Perform cardio-pulmonary resuscitation. } \\
13 \text { Utilise an ambubag resuscilator. } \\
14 \text { Monitor a respirator. } \\
15 \text { Administer an enema. }\end{array}$ & $\begin{array}{l}29 \\
29 \\
27 \\
28 \\
28 \\
28 \\
28 \\
28 \\
29 \\
29 \\
29 \\
29 \\
29 \\
29 \\
29\end{array}$ & $\begin{array}{l}37 \\
38 \\
45 \\
35 \\
38 \\
29 \\
41 \\
18 \\
38 \\
41 \\
24 \\
41 \\
45 \\
35 \\
36\end{array}$ & $\begin{array}{l}25 \\
36 \\
43 \\
43 \\
43 \\
79 \\
39 \\
33 \\
41 \\
31 \\
17 \\
25 \\
35 \\
18 \\
37\end{array}$ \\
\hline
\end{tabular}

psychiatric clinical units. Such practices would provide teaching opportunities for NQNs and would also help them observe the principle of nursing the patient in totality.

As reflected in Table 3 the SPNs regarded the clinical accompaniment of student nurses in the psychiatric units, by clinical preceptors and tutors, as a possible cause contributing towards NQNs' incompetencies. This might be the case because frequent accompaniment of the students obviates the need for these students to make inde- 
pendent decisions concerning nursing care interventions. This inability is perceived as incompetence by the SPNs. Further investigations would need to be done to enhance the value of tutors' clinical accompaniment of student nurses in the psychiatric clinical units in the Northern Province.

The attitudes of NQNs in the psychiatric units were perceived by the SPNs to be contributing towards NQNs' incompetencies. Fifty-five percent of SPNs commented that their own negative attitudes might have contributed towards the NQNs' incompetencies. The findings seem

TABLE 3: SPN'S PERCEPTIONS OF CAUSES WHICH COULD CONTRIBUTE TOWARDS NQN'S INCOMPETENCY.

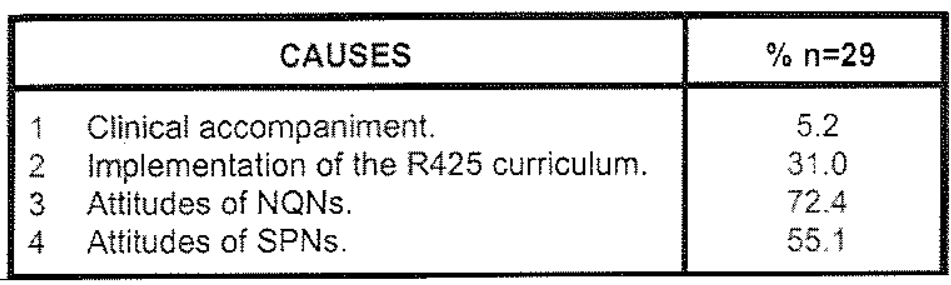

to be supported by various studies. Girot (1993) revealed that sisters commented that newly qualified graduates knew nothing and that they actually expected to be "spoon-fed" all the way. Lathlean \& Corner (1991) also indicated staff attitudes as a major reason affecting newly registered nurses' competency. Lowane (1990) revealed that sisters' attitudes were a hindrance to student nurses' learning in the clinical settings in the Northern Province.

\section{LIMITATIONS OF THE RESEARCH PROJECT}

This study merely investigated the general views of the SPNs regarding the competencies of NQNs working in psychiatric nursing units in the NP. The actual competencies of the NQNs were neither evaluated by themselves or by the researcher. Future studies could ask the NQNs to evaluate their own competencies and use observers to evaluate the competencies of the NQNs on specific aspects/functions.

Bi-annual follow-up surveys might be essential to account for changes taking place in both nursing education programmes and in the psychiatric nursing services in the Northern Province and to assist SPNs, nurse edu- cators and nurse preceptors to enhance the psychiatric nursing competencies of the NQNs in the Northern Province.

\section{CONCLUSIONS AND RECOMMENDATIONS}

The study revealed that NQNs appeared to lack competency to perform important cognitive, psychomotor and affective nursing functions in the psychiatric units. This perception is supported by Benner (1984) who undertook a research study in California, USA, of beginning and expert nurses to determine differences in their clinical performances. Benner's findings describe the NQN as a novice, one who is only just beginning to develop the expertise needed to provide clinical care. Benner asserts that the stages of competency acquisition fall into five broad categories namely: the novice, the advanced beginner, the competent practitioner, the proficient practitioner, and the expert practitioner. Recognition of these phases could, to some extent, overcome the feelings of inadequacy which are often experienced in the early days after qualifying. It is unrealistic to think that expert practice will be achieved immediately. The findings of the study indicate that NQNs should be provided with in-service education programmes to facilitate their adaptation to the psychiatric nursing units. Such programmes could also enhance the productivity of the NQNs and their sense of job satisfaction.

Based on the research findings obtained during this exploratory descriptive survey, future research should investigate:

- Clinical accompaniment by nurse educators.

- SPNs' attitudes towards teaching student nurses assigned to their in their units.

- Essential competencies as perceived by NQNs upon entering the work setting.

- Whether orientation programmes could enhance NQNs' competencies in the psychiatric units.

Such information could provide curriculum developers with realistic inputs about the NQNs' expected competencies and perceived competencies upon entering the psychiatric health care services. Such information is 
required to formulate realistic outcomes for students following psychiatric nursing courses. The services of psychiatric nurses, and for psychiatric and mental health nursing are likely to increase on the African continent with the continuation of civil and trans-border armed conflicts escalating throughout the continent (Adejumo, 1999:240). This study attempted to identify NQNs' competencies expected by SPNs in the psychiatric units in the Northern Province. However, future research would need to determine whether or not these identified competencies are indeed relevant to the people's or communities' health care needs.

Vague and nebulous is the beginning of all things, but not their end, and I fain would have you remember me as a beginning. Life, and all that lives, is conceived in the mist and not in the crystal.

And who knows but a crystal is mist in decay?

(Kahlil Gibran)

\section{BIBLIOGRAPHY}

Adejumo, O 1999: Models of psychiatric nursing education in developing countries: a comparative study of Botswana and Nigeria. Unpublished D Litt. et Phil thesis. Pretoria: University of South Africa.

Benner, P 1984: From novice to expert: Excellence and power in clinical nursing practice. California: AddisonWesley.

Burns, N \& Grove, SK 1987: The practice of nursing research: conduct, critique and utilization. Philadelphia: WB Saunders.

Cooney, AT 1992: An orientation program for new graduate nurses: The basis of staff development and retention. Journal of Continuing Education in Nursing, 23(5):216-219.

Doornbos, MM 1997: The problems and coping methods of caregivers of young adults with mental illness.

Journal of Psychosocial Nursing, 35(9):22-26.
Edwards, K 1995: A preliminary study of users' and nursing students' views of the role of the mental health nurse. Journal of Advanced Nursing, 21(2):222-229.

Ehrenfeld, M \& Eckerling, S 1991: Perceptions and attitudes of registered nurses of research: A comparison with a previous study. Journal of Advanced Nursing, 16(2):224-232.

Feeley, N \& Gerez-Lirette, T 1992: Development of professional practice based on the McGill model of nursing in an ambulatory care setting. Journal of Advanced Nursing, 17(7):801-807.

Feely, M 1997: Using Peplau's theory in nurse-patient relations. International Nursing Review, 44(4):115119.

Fitzpatrick, JM; White, AC \& Roberts, JD 1992: The role of the nurse in high - quality patient care: A review of the literature. Journal of Advanced Nursing, 17(10):1210-1219.

Gujbels, H 1995: Mental health nursing skills in an acute admission environment: perceptions of mental health nurses and other mental health professionals. Journal of Advanced Nursing, 21(3):460-465.

Girot, EA 1993: Assessment of competency in clinical practice: A phenomenological approach. Journal of Advanced Nursing, 18(1):114-119.

Joyce-Nagata, B; Reeb, R \& Burch, S 1989: Comparison of expected and evidenced baccalaureate degree competencies. Journal of Nursing Education, 28(7):314-320.

Khoza, LB 1997: The competencies of newly qualified nurses as viewed by senior professional nurses. Unpublished D Litt. et Phil thesis. Pretoria: Unisa. Landeen, J; Byrne, C \& Brown, B 1995: Exploring the lived experiences of psychiatric nursing students through self-reflective journals. Journal of Advanced Nursing, 
21(5):878-885.

Lathlean, J \& Corner, J 1991: Becoming a staff nurse: A guide to the role of the newly registered nurse. New York: Prentice Hall.

Lowane, LB 1990: Student nurses' perceptions of clinical learning experiences. Unpublished MA Cur dissertation, Pretoria: Unisa.

Monkley-Poole, S 1995: The attitudes of British fundholding general practitioners to community psychiatric nursing services. Journal of Advanced Nursing, 21(2):238-247.

Polit, DF \& Hungler, BP 1989: Essentials of nursing research: methods, appraisal, and utilization; $2^{\text {nd }}$ edition. Philadelphia: Lippincott.

RHOSA 1992: Memorandum to the subcommittee on nursing. Health Matters Committee (HMC) and Regional Health Organisation of South Africa (RHOSA).

SANC - see South African Nursing Council.

Searle, C \& Pera, S 1992: Professional practice: a South African nursing perspective. Durban: Butterworths.

South African Nursing Council 1992: Teaching guide for the programme leading to registration as a nurse (general, psychiatric and community) and midwife. Pretoria: Government Printer.

South African Nursing Council 1984: Regulations relating to the scope of practice of persons who are registered or enrolled under the Nursing Act, 1978. Regulation R2598 of November 1984. Pretoria: Government Printer.

Troskie, R 1993: Critical evaluation of the newly qualified nurse's competency to practise. Curationis, 16(3):50-61. 